\title{
SUPERVISORY AUTHORITIES AND QUASI-AUTHORITIES IN COMMUNE-LEVEL LOCAL GOVERNMENT
}

\begin{abstract}
The subject of the analysis carried out in the paper is the characteristics of supervisory authorities. What is extremely important is that both constitutional authorities and quasi-authorities have the power to conduct supervisory activities, but only in terms of legality. The object of supervision is not only normative acts adopted by commune-level local government bodies, but also other activities carried out by entities that operate at this level of government.

The competences of supervisory authorities are compared with those of quasisupervisory authorities. Some quasi-supervisory authorities (e.g. administrative courts) are able to verify the supervisory decisions of constitutional supervisory authorities. This relationship preserves the independence of communes. The exception is the supervisory competence of the lower chamber of Poland's parliament (Sejm), whose supervisory acts are not subject to appeal - this is a unique exception to the constitutional principle of two-instance proceedings.

Because of its brief size, the present paper is not an attempt at a comprehensive presentation of the problem identified in the title. The discussion is limited to a few elements. The paper contains an analysis of selected issues related to the problem of supervision over the activities of commune-level local government. The problem was described by comparing the most important constitutional and non-constitutional authorities appointed for this purpose.

I started my deliberations with an analysis of general issues related to both constitutional supervisory authorities and "quasi-supervisory" authorities. Then
\end{abstract}


I provided a brief description of such authorities as province governor, prime minister, regional chamber of accounts, Sejm, local government board of appeal, and administrative courts.

Almost every part of the paper refers to numerous views expressed in the doctrine, the current legislation, and the relevant case law. Without presentation of the case law, correct interpretation of the issues in question would not have been possible. The paper ends with a brief summary.

KEYWORDS: supervisory authorities, Sejm, province governor, regional chamber of accounts, prime minister, local government board of appeals, administrative courts

\section{Preliminary COMments}

the purpose of the paper is to provide a brief description of both supervisory authorities and quasi-supervisory authorities that have supervisory powers in relation to, among others, the local government. As it is not possible to make an in-depth presentation of the matter indicated in the title in such a brief paper, my deliberations will focus only on the basic issues. The paper does not discuss the concepts of "supervision" and "control," nor does it provide a detailed analysis of the concepts of "object of supervision," "supervision criteria," and "supervisory measures" (more information on this topic can be found in: S. Bułajewski, 2009, pp. 221-235).

Inevitably, the starting point for the deliberations is Article 171(2) of the Constitution of the Republic of Poland, which clearly provides: "The bodies supervising the activities of local and regional government units are the prime minister and province governors, and, as regards financial matters, regional chambers of account" (Constitution of the Republic of Poland of 2 April 1997, Journal of Laws of 1997, no. 78, item 483, as amended). The laws that regulate the system of local and regional government also indicate that the powers concerning application of supervisory measures over local and regional government units are also vested in the Sejm and the minister in charge of public administration (see, for example, Articles 96-98 of the Act of 8 March 1990 on commune-level local government, consolidated text: Journal of Laws of 2020, item 713, as amended).

In my opinion, administrative courts and local government boards of appeal also have certain supervisory powers. 


\section{SUPERVISORY AUTHORITIES IN THE STRICT MEANING OF THE TERM}

Supervisory authorities, in the strict meaning of the term, include province governors, the prime minister, and regional chambers of accounts. The province governor certainly plays the leading role among the aforementioned authorities.

\section{Province governor}

The province governor has been a constitutional state authority since 1990. Article 152 of the Constitution of the Republic of Poland of 2 April 1997 provides that "the representative of the Council of Ministers in a province is a province governor" and that "the procedure for appointment and dismissal, and the scope of activities of province governors are defined in a statute." Thus, both Article 152 and Article 171(2) of the Constitution define the normative position of this authority and form the basis for defining the position of a province governor in ordinary statutes. A province governor acts in the political sphere as a representative of the council of ministers and exercises his or her powers as a supervisory authority guided by the criterion of legality. The province governor also performs the function of a public administration body, one of whose tasks is to decide on the rights and obligations of administrative entities (M. Chmaj, 2012, pp. 129-130).

A province governor is appointed and dismissed by the prime minister at the request of the minister in charge of public administration (art. 6(1) of the Act of 23 January 2009 on the province governor and government administration in a province; consolidated text: Journal of Laws of 2019, item 1464). The appointment and dismissal of a province governor is made by means of an administrative act. This is the main legal form of operation of public administration, which is an authoritative decision (declaration of will) of a public administration body based on provisions of administrative law, issued in a specific case and concerning an individually specified addressee (more information on this topic can be found in: E. Komorowski, 2007, pp. 245-254 - quoted after Komorowska M. Chmaj, 2012, p. 131).

With regard, however, to the most important issues that arise, among others, from the title of the paper, it should be clearly stated that in the system 
of supervision over local and regional government units, a province governor holds a special position (in accordance with Article 3 of the Act on the province governor and government administration in a province, a province governor, apart from supervising the activities of local and regional government units and their associations, also has a number of different competences). One should also keep in mind that the sources of the competences related to supervision are not only the statutes that govern the system of local and regional government, but also many special statutes. A manifestation of a province governor's supervisory powers is the possibility to implement many supervisory measures. These include not only repressive actions, but also preventive and control actions that precede the relevant supervisory acts connected with ongoing supervision or emergency situations (Z. Kmieciak, M. Stahl, 2001, p. 97). A province governor uses his or her supervisory powers most often in connection with the resolution-passing activity of the decisionmaking and executive units of local and regional government. Supervisory proceedings (during which the supervisory authority examines whether or not a resolution of a body of a unit of local or regional government complies with law) end (although very rarely) with a supervisory decision issued by the province governor. According to J. Zimmermann's definition, a supervisory decision is "an act of a supervisory authority that ends a supervisory proceeding and specifies the supervisory measure that the authority intends to implement" (J. Zimmermann, 1991, pp. 43-53).

An important power of a province governor is to issue substitute orders in cases where local and regional government bodies fail to act when persons holding public offices break the rules concerning restrictions on conducting business activity (Article 98a of the Act on commune-level local government). A province governor also has supervisory powers related to application of specific measures by the prime minister (Art. 96(2) and Art. 97(3) of the Act on commune-level local government).

\section{Regional chambers of account}

Adoption of the Act of 7 October 1992 on regional chambers of accounts (consolidated text: Journal of Laws of 2019, item 2137) followed the announcement made in Article 62 (1) of the Act of 8 March 1990 
on local and regional government (consolidated text: Journal of Laws of 1996, no. 13, item 74, as amended), which adopted the principle that "the financial management of communes and their associations shall be audited by regional chambers of account." A similar provision can also be found in the Act on commune-level local government (Article 62). The Constitution of the Republic of Poland of 1997 (in the aforementioned Article 171(2)) for the first time included regional chambers of account in the system of public administration bodies established pursuant to the Constitution. Regional chambers of accounts are state authorities that are in charge of supervision and audit of the financial management of local and regional government entities. The above proposition is also confirmed by the view presented by the Constitutional Tribunal in its judgment of 28 April 1999 (file no. K 3/99, OTK 1999, no. 4, item 26; see also: T. Turek, 2002, pp. 58-59).

Both the Act on the commune-level local government and the Act on regional chambers of account distinguish two basic powers of the chambers, i.e. audit and supervisory powers. In addition, the chambers issue opinions on matters set forth in statutes and carry out information, instruction, and training activities within the scope covered by their audit and supervision powers.

Pursuant to Article 1( 1 and 2) of the Act on regional chambers of accounts, the chambers supervise the activities of local and regional government units with regards to the financial matters specified in Article 11(1) and audit the financial management and public procurement activities of:

1) local and regional government units; 1a) metropolitan unions;

2) inter-commune unions;

3) associations of communes and associations of communes and districts;

4) unions of districts;

4a) unions of districts and communes;

5) associations of districts;

6) organizational local and regional government units, including local and regional government legal persons;

7) other entities, as regards their use of subsidies granted from the budgets of local government units. 
In accordance with the aforementioned Article 11(1) of the Act on regional chambers of accounts, the competence of regional chambers of accounts regarding supervisory activities includes resolutions and orders adopted by local and regional government bodies in the following matters:

1) budget adoption and modification procedures;

2) the budget and its modifications;

3) incurring liabilities that affect the value of public debt of a local government unit and granting of loans;

4) the principles and scope of granting of subsidies from the budget of a local government unit;

5) local taxes and charges to which the provisions of the Tax ordinance apply;

6) the vote of acceptance;

7) the multiannual financial forecast and its changes.

A special type of a supervisory decision made by the chamber is the establishment of a commune's budget in the event of inactivity of the resolution-passing body in this regard (the so-called substitute budget adoption).

Pursuant to Article 11(2), in the event of failure of the decision-making body of a local or regional government unit to adopt a budget resolution by 31 January of the financial year, the chamber establishes the budget of such unit by the end of February of the financial year to cover the unit's own tasks and commissioned tasks. In accordance with Article 11(2a), the chamber establishes the budget of a local government unit to cover its own tasks and commissioned tasks also in the event of failure of that unit to observe the principles set out in Articles 242-244 of the Act of 27 August 2009 on public finance (consolidated text: Journal of Laws of 2019, item 869, as amended).

In the case of an insignificant violation of the law in a resolution or order, the chamber does not declare the resolution or order invalid, but limits itself to indicating that it had been issued in violation of the law (more information on the competences of regional chambers of accounts can be found in: S. Bułajewski, 2009, pp. 239-245). 


\section{Prime minister}

As set forth in Article 148(6) and Article 171(2) of the Constitution, the function of supervision over, among others, the commune-level local government was concentrated in the hands of the prime minister (P. Sarnecki, 2002, p. 246). However, in his or her supervisory intervention activities, the prime minister does not refer directly to normative acts adopted by commune authorities, but concerns its organizational structures (Z. Kmieciak, M. Stahl, 2001, p. 111). Therefore, such activities are referred to as external personal supervisory measures (B. Dolnicki, 1999, p. 187). In its resolution of 5 October 1994, the Constitutional Tribunal stated that the measures provided for in Article 96 of the Act on commune-level local government "[...] are not, in the strict sense of the term, measures of supervision over municipal activity, but repressive and disciplinary measures in relation to local government bodies" (W 1/94 (Journal of Laws of 1994, no. 113, item 551)).

The supervisory powers of the prime minister are regulated in Chapter 10 of the Act on commune-level local government. They include:

According to Art. 96(1) of the Act on commune-level local government, in the event of repeated violations of the Constitution or statutes by a commune council, the Sejm, at the request of the prime minister, may dissolve the commune council by way of a resolution. In the event of dissolution of a commune council, the prime minister, at the request of the minister in charge of public administration, appoints a person to perform its function until the commune council is elected. If a repeated violation of the Constitution or statutes is committed by the head of a commune, the province governor calls upon the head of the commune to cease the violations, and if this call is not successful, he or she requests the Prime Minister to dismiss the head of commune. In the event of dismissal of a head of a commune, the prime minister, at the request of the minister in charge of public administration, appoints a person to perform the dismissed person's function until the head of the commune is elected.

According to Art. 97 of the Act on commune-level local government, if there is no hope for a quick improvement and a prolonged lack of effectiveness in the performance of public tasks by a commune's authorities, the prime minister, at the request of the minister in charge of public administration, 
may suspend the commune's authorities and impose forced administration for up to two years, but no longer than until the election of the commune council and the head of the council for the next term. Forced administration may be established after prior presentation of the allegations to the commune's authorities and after they have been urged to submit without delay a program for improvement of the situation of the commune. The government commissioner is appointed by the prime minister at the request of the province governor submitted through the minister in charge of public administration. A government commissioner takes over the performance of the tasks and powers of the commune's authorities on the day of his or her appointment.

\section{QUASI-SUPERVISORY AUTHORITIES}

in my opinion, quasi-supervisory authorities, i.e. authorities that have supervisory powers in relation to local and regional government units including communes, include: the Sejm, local government boards of appeal, and administrative courts.

\section{Sejm}

the Sejm has exceptional supervisory powers related to the system of government. Article 171(3) of the Constitution clearly provides that: "The Sejm, at the request of the prime minister, may dissolve a decision-making body of the local or regional government if this body grossly violates the Constitution or statutes." The equivalent of the above-mentioned constitutional norm in the Act on commune-level local government is the latter's Art. 96(1). The prerequisite for application of this supervisory measure under this Article is repeated violation by the commune council of the Constitution or statutes. There seems to be some inaccuracy in the content of this provision, because the constitutional norm provides that the basis for the application of this measure is "gross violation of the Constitution or statutes," while the Act only mentions repeated violation of the Constitution and statutes, which does not necessarily have to be a gross violation of law. However, both the constitutional provision and the provisions of the Act 
allow for the possibility of dissolution of a commune council only in the case of repeated (and, therefore, not one-off) violation of the Polish Constitution or statutes by the council. Violation (even repeated) by a decision-making authority of acts of law whose order is lower than that of a statute can never constitute a premise for this drastic supervisory measure.

However, one must keep in mind that only the three supervisory authorities indicated in Article 171(2) of the Constitution may exercise supervision ex officio, whereas the Sejm may act only upon request. Thus, the Sejm cannot be classified as a supervisory authority in the strict sense of the term (Z. Janku, 2001, p. 187). Dissolution of a resolution-passing body of a commune results in dissolution, by virtue of law, of all the bodies of that local government unit. For the period until new commune authorities are elected, the prime minister appoints, at the request of the minister in charge of public administration, a person to perform the function of these authorities. This person, in the course of his or her duties, is considered to be the legal representative of all commune authorities, and thus is subject to supervision (B. Dolnicki, 2005, p. 490).

In the event of dissolution of a decision-making body of a commune by a resolution of the Sejm, a complaint against such resolution filed with an administrative court is not admissible, because the Sejm is not expressly defined as a supervisory authority anywhere and because judicial control concerns supervisory decisions in relation to operation of commune authorities and not such authorities themselves (K. Podgórski, 1991, pp. 34-35).

For these reasons, this exceptional supervisory measure should be used only in exceptional situations.

\section{Local government boards of appeal}

Pursuant to Article 1(1) of the Act of 12 October 1994 on local government boards of appeal (consolidated text: Journal of Laws of 2018, item 570), local government boards of appeal are higher-level bodies, within the meaning of the provisions of the Code of Administrative Procedure and the Act of 29 August 1997 - Tax Ordinance, in individual public administration matters falling within the competence of local and regional government units, unless specific laws provide otherwise. 
In the system of government, local government boards of appeal are separate from local government units and are independent in terms of their adjudication. However, there have been serious doubts as to the determination of the legal nature of local government boards of appeal, which in no way can be classified as government administration bodies, but only as a part of a broadly defined system of local and regional government (judgment of the Constitutional Tribunal of 28 April 1999, K 3/99, OTK ZU 1999, no. 4, item 73).

Without discussing the legal nature, jurisdiction, and organization of the local government boards of appeal, I will only refer to the supervisory powers given to the boards regardless of their main judicial activity. These powers include:

- the power to demand information and documents necessary to issue verdicts concerning the activities of bodies of local government units (Art. 19(2)(1) of the Act on local government boards of appeal);

- the right to inspect documentation related to the handling of matters that are the object of the verdicts issued by the boards (Article 19(2)(2) of the Act on local government boards of appeal); and

- the right to issue signaling decisions (Article 20 of the Act on local government boards of appeal).

The first two powers are merely intended to provide the boards with all the information necessary for a proper resolution of cases. It is therefore not possible for the boards to use such documents and information for any other purpose, since that would go beyond the limits of the powers conferred upon them and would consequently lead to a clear violation of law (J.P. Tarno, 1995, p. 31; M. Kotulski, 2002, pp. 74-75).

As far as signaling decisions are concerned, they are issued by the president of the board in the event of significant deficiencies in the work of a local government unit body (in a commune, it is the council or the commune head/town mayor/city president). A copy of the such a decision is forwarded to the local government unit body and, separately, to the audit committee of the commune council and the competent province governor. It may be the basis for initiating disciplinary proceedings against local government employees if their acts or omissions are the cause of the deficiencies in 
the work of the commune body. In addition, issuing a signaling decision creates an obligation on the part of the commune bodies to inform the local government board of appeal within 30 days about their position. As is not possible to lodge a complaint against the above-mentioned decision, in this particular case the proceedings are not conducted in more than one instance. This power is mainly intended to discipline commune bodies to work within their administrative jurisdiction. The origins of the signaling institution formulated in the Act on local government boards of appeal go back to the no longer effective Art. 214 of the Code of Administrative Procedure (A. Korzeniowska, 2002, p. 278). The doctrine's views concerning recognition of the signaling decision issued by the president of the local government board of appeal as a kind of an act of supervision over local government are not uniform (L. Żukowski, R. Suwała, 2001, p. 244; Z. Kmieciak, 2001, p. 97).

Granting these powers to the local government boards of appeal must be considered as a good thing. There is no form of hierarchical dependence between the commune-level local government and the local government boards of appeal. As a result, the nature and scope of the powers in question, which are similar to supervisory measures, do not violate the autonomy and independence of communes. There is only an indirect control effect, without the possibility to impose any sanctions against commune bodies. Thus, the principle of decentralization expressed in the Constitution is not threatened in this regard (D. Dąbek, J. Zimmermann, 2005, p. 40).

\section{Administrative courts}

the basic duty of the administrative courts in relation to local and regional government units is judicial control of public administration and, consequently, the commune-level administration; this is a systemic guarantee of a democratic law-abiding state (the relevant principal legal act is the Act of 25 July 2002 on the system of administrative courts; consolidated text: Journal of Laws of 2019, item 2167, as amended). This is why Article 184 of the Constitution provides that "the Supreme Administrative Court and other administrative courts exercise control over the activities of public administration bodies to the extent specified in a statute. This control also includes adjudicating on the compliance of resolutions of local government 
bodies and normative acts of local government administration bodies with statutes." This provision is inextricably linked to the judicial protection of independence of local and regional government units, i.e., the principle expressed in Article 165(2) of the Constitution (more information on this topic can be found in: J. P. Tarno, 2006, p. 87-88).

In my opinion, however, administrative courts are also a kind of quasisupervisory authority in relation to activities of communes, especially their legislative activities.

The legal institution aimed to ensure judicial protection of independence of communes in relation to supervisory interference is the possibility to lodge an appeal against supervisory decisions (containing both corrective and personal supervisory measures) with an administrative court, for noncompliance with law, within 30 days of their delivery. A supervisory decision becomes final on the expiry of the time limit for lodging an appeal or on the date of dismissal or rejection of the appeal by the court (more information on this topic can be found in: B. Adamiak, J. Borkowski, 1991, pp. 38-45; T. Rabska, 1991, p. 46-50; W. Chrościelewski, 1994, pp. 49-58). On the other hand, if the supervisory decision is delivered after the expiry of the term of office of the commune council, a complaint against the decision may be lodged by the newly elected decision-making body of the commune. In this case, the 30-day time limit starts only on the day on which the chairman of the municipal council is elected.

Protection of a commune's independence is not limited to lodging complaints against acts of supervision over the commune's activity with an administrative court. It also includes the legal possibility of elimination of the so-called competence disputes that involve the bodies of a commune. Disputes over jurisdiction between commune bodies and bodies of other local and regional government units (district and province) or central government administration bodies are resolved by administrative courts. Thanks to the above-mentioned regulation, a commune may protect its independence and autonomy in terms of the tasks assigned to it before an administrative court in the case of illegal interference by both the district- or province-level local and regional government and a central government administration body (see more: Sitek, 2016, 212). 


\section{Conclusion}

The purpose of this paper is to briefly describe the supervision over commune-level local government by both supervisory authorities in the strict meaning of this term and institutions that are considered quasisupervisory authorities. On the one hand, these are constitutional bodies that operate, among others, in the political sphere (this remark refers to the prime minister and province governors) and, on the other hand, these are supervisory authorities bodies (which in our case supervise the activities of local government units) that exercise their powers by following the criterion of legality (this group also includes regional chambers of accounts). My intention was to present also the quasi-supervisory authorities that, in addition to the authorities specifically mentioned in Article 171(2) of the Constitution, have some features of supervisory authorities. An analysis of the deliberations presented herein leads to some conclusions.

First, the province governor, the prime minister, and the regional chambers of accounts are the constitutional bodies of the state that the legislator has established as the bodies charged with supervision over local and regional government.

Second, the inclusion of supervisory authorities in the Constitution leads to a number of systemic effects. Elimination of these bodies, or even their transfer to a decentralized administration, is not possible without an amendment to the currently Constitution.

Third, the independence granted to the local and regional government is manifested in the normative structure of supervision. The Constitution provides for two main elements of the structure of supervision over local and regional government units: first, the criterion of supervisory interference - i.e. legality (Article 171 (1) of the Constitution); second, the bodies established to carry out supervision, with the powers conferred upon them in this respect in accordance with Article 171 (2) of the Constitution.

Fourth, the supervisory authorities indicated in the Constitution, regardless of their supervisory powers, have control powers.

Fifth, the supervisory procedure is a one-instance procedure. Both its suspension and its revocation are subject to appeal to a Provincial Administrative Court. 
Sixth, not all quasi-supervisory bodies (local government boards of appeal) are established in the Constitution, which does not mean that they are not able to control or to exercise fragmentary supervision over the operations of, among others, the commune-level local government.

Seventh, both the supervisory authorities in the strict meaning of this term and the quasi-supervisory authorities complement each other in an excellent way: the former can, among other things, repeal resolutions passed by local and regional government bodies and the latter (administrative courts) guard the independence of communes.

\section{References:}

Adamiak B., Borkowski J. (1991), Instytucje prawne sąowej ochrony samodzielności gminy [Legal institutions for judicial protection of independence of communes], "Samorząd Terytorialny", nr 1-2. ISSN 0867-4973.

Bułajewski S. (2009), Rada powiatu, pozycja ustrojowa, stanowienie prawa i kontrola [County council, position in the system of government, law-making, and control], Olsztyn: Wydawnictwo Uniwersytetu Warmińsko-Mazurskiego. ISBN 9788372996268.

Chmaj M. (2012), Wojewoda, urząd wojewódzki [Province governor and province governor's office], in: M. Chmaj, ed., Administracja Rzadowa w Polsce [Government administration in Poland], Warsaw: Difin. ISBN 9788376415956.

Chrościelewski W. (1994), Sądowa kontrola rozstrzygnięć nadzorczych dotyczacych samorzadu terytorialnego [Judicial control of supervisory decisions concerning local and regional government], "Samorząd Terytorialny", no. 10. ISSN 08674973.

Dąbek D. (2005), Zimmermann J., Decentralizacja poprzez samorząd terytorialny $w$ ustawodawstwie i orzecznictwie pokonstytucyjnym [Decentralization through local and regional government in the laws and court rulings after adoption of the constitution], in: P. Sarnecki (ed.), Samorzad terytorialny zasady ustrojowe $i$ praktyka [Local and regional government, system of government principles and practice], Warsaw: Wydawnictwo Sejmowe. Kancelaria Sejmu. ISBN 8370597394.

Dolnicki B. (2005), Komentarz do art. 85 ustawy o samorzadzie powiatowym [A commentary to Article 85 of the Act on district-level local government], in: B. Dolnicki, red., Ustawa o samorzadzie powiatowym komentarz [Act on districtlevel local government, a commentary], Kraków: Zakamycze. ISBN 8374441186. 
Dolnicki B. (1999), Samorzad terytorialny zagadnienia ustrojowe [Local and regional government, issues related to the system of government], Kraków: Zakamycze. ISBN 8388114484.

Janku Z. (2001), Nadzór nad samorząem powiatowym [Supervision over the districtlevel local government], in: J. Boć, ed., Powiat. Z teorii, kompetencje, komentarz [District. Theory, competences, a commentary], Wrocław: "Kolonia Limited". ISBN 8388166336.

Kmieciak Z., Stahl M. (2001), Akty nadzoru nad działalnościa samorzadu terytorialnego [Acts of supervision over the activities of local and regional government], "Samorząd Terytorialny", no. 1-2. ISSN 0867-4973.

Komorowski E. (2007), Prawne formy działania administracji [Legal forms of activities of the administration], in: M. Chmaj, ed., Prawo administracyjne. Część ogólna [Administrative law. General part], Warsaw - quoted after Chmaj M., Wojewoda, urząd wojewódzki [Province governor and province governor's office], in: M. Chmaj, ed., Administracja Rządowa w Polsce [Government administration in Poland], Warsaw: Difin. ISBN 9788376415956. 2012.

Korzeniowska A. (2002), Postępowanie przed samorzadowym kolegium odwoławczym [Proceedings before a local government board of appeals], Kraków: Zakamycze. ISBN 8373331190.

Kotulski M. (2002), Samorzadowe kolegia odwoławcze (Wybrane problemy prawnoustrojowe) [Local government boards of appeal (Selected legal and system of government issues)], “Gdańskie Studia Prawnicze”, vol. 8. ISSN 1734-5669.

Podgórski K. (1991), Nadzór nad samorządem gminnym [Supervision over communelevel local government], "Samorząd Terytorialny", no. 1-2. ISSN 0867-4973.

Rabska T. (1991), Sadowa ochrona samodzielności gminy [Judicial protection of independence of communes], "Samorząd Terytorialny", no. 1-2. ISSN 0867-4973.

Sarnecki P. (2002), Zakres działania i funkcje Rady Ministrów [The scope of operation and functions of the council of ministers], in: A. Bałaban, ed., Rada Ministrów organizacja ifunkcjonowanie [Council of ministers - organization and functioning], Kraków: Zakamycze. ISBN 8373331727.

Sitek M. (2016) Prawa (potrzeby) człowieka w ponowoczesności, Warszawa: C.H.Beck. ISBN 9788325589226.

Tarno J. P. (1995), Samorzadowe kolegia odwoławcze [Local government boards of appeal], "Samorząd Terytorialny", no. 4. ISSN 0867-4973.

Tarno J.P. (2006), Zakres działania sądów administracyjnych [Scope of activities of administrative courts], in: J. P. Tarno, E. Frankiewicz, M. Sieniuć, M. Szewczyk, J. Wyporska, Sądowa kontrola Administracji [Judicial control of administration], 
Warsaw: Europejska Wyższa Szkoła Prawa i Administracji : Wydawnictwo Zrzeszenia Prawników Polskich. ISBN 9788387218362.

Turek T. (2002), Pozycja ustrojowa regionalnej izby obrachunkowej jako podmiotu kontroli wewnętrznej Gminy [The position of the regional chamber of accounts, as an internal control entity of a commune, in the system of government], in: S. Dolata, ed., Problemy prawne $w$ działalności samorzadu terytorialnego [Legal problems in the activities of local and regional government], Opole: Wydawnictwo Uniwersytetu Opolskiego. ISBN 8388796763.

Zimmermann J. (1991), Elementy procesowe nadzoru i kontroli NSA nad samorządem terytorialnym [The process elements of supervision and control of the Supreme Administrative Court over the local and regional government], "Państwo i Prawo", book 10. ISSN 0031-0980.

Żukowski L., Suwała R. (2001), Postępowanie administracyjne i postępowanie przed naczelnym Sadem Administracyjnym [Administrative procedure and procedure before the Supreme Administrative Court], Warsaw, p. 244; Z. Kmieciak, Nota bibliograficzna [Bibliographic note], "Państwo i Prawo", book 6. ISSN 0031-0980.

\section{Normative acts and rulings}

Judgment of the Provincial Administrative Court in Gorzów Wielkopolski of 28 November 2018 (file ref. no. II SA/Go 779/18).

Judgment of the Provincial Administrative Court in Olsztyn of 16 June 2015, (file ref. no. II SA/Ol 433/15).

Judgment of the Provincial Administrative Court in Bydgoszcz of 8 January 2009 (file ref. no. II SA/Bd 878/08).

Act of 14 June 1960 - Code of Administrative Procedure (consolidated text: Journal of Laws of 2020, item 256, as amended).

Act of 23 April 1964 - Civil Code (consolidated text: Journal of Laws of 2019, item 1145).

Act of 8 March 1990 on commune-level local government (consolidated text: Journal of Laws of 2020, item 713).

Act of 20 December 1996 on municipal management (consolidated text: Journal of Laws of 2019, item 712, as amended).

Constitution of 2 April 1997 (Journal of Laws of 1993, no. 61, item 284, as amended). 
Act of 21 August 1997 on restriction of business activity by persons holding public offices (consolidated text: Journal of Laws of 2019, item 2399).

Act of 29 August 1997 - Tax Ordinance (consolidated text: Journal of Laws of 2017, item 201, as amended).

Act of 15 September 2000 - Commercial Companies Code (consolidated text: Journal of Laws of 2019, item 505, as amended).

Decision of the Supreme Administrative Court of 26 May 2015 (file ref. no. II FSK 826/13).

Act of 11 January 2018 amending certain acts in order to increase the participation of citizens in the process of electing, functioning, and controlling certain public bodies (consolidated text: Journal of Laws of 2018, item 130, as amended).

Judgment of the Supreme Administrative Court of 29 August 2019 (file ref. no. I OSK 657/19). 
